\title{
Waste Reduction Plan for Cut-Edge Private Limited: A Case Study
}

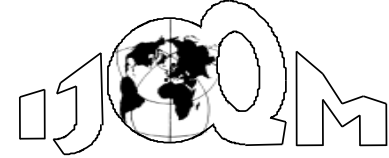

DOI: $10.46970 / 2021.27 .2 .5$

Volume 27, Number 2

\author{
Chetan A. Jhaveri \\ Anuja Ajayprakash Gupta \\ Nirma University \\ (chetan@ nirmauni.ac.in) \\ (anujagupta2003@gmail.com)
}

June 2021, pp. 153-158

Cut-Edge Private Limited operates into cutting steel angles from the various parts available in different lengths, for the construction of bridges and transmission/power towers. The management team is interested in analyzing the production problem for optimum use of resources. Linear Programming is the widely used technique to obtain production plans for such problems and thus minimizing the waste while optimally utilizing the available resources. Microsoft Excel's Solver has been used in this case to strategize various feasible combinations for cutting the steel angles. The case widens the student's scope for Linear Programming Problem.

Keywords: Linear Programming, MS-Solver, Optimization Problem, Waste Reduction

\section{Case Learning Objectives}

This case can be used in core courses of Production \& Operations Management, Operations Research and Decision Science under the sub topics like Linear Programming and Optimization Model.

1. After discussing this case, students will be able to explore mathematical modelling using Linear Programming (LP) as an optimizing tool in Operations Research.

2. After discussing this case, students will be able to demonstrate their understanding of MS Excel- Solver which is used to get optimal solution for resource allocation model using the LP.

3. After discussing this case similar organizations in this industry will be able to examine and then demonstrate their problem to reduce high material wastage as well as the cost associated to it, by coming up with appropriate combinations of different parts in different quantities using LP as an optimization model tool of OR.

\section{Case Plot}

Aakash was sitting in his office trying to think for a solution to the problem the company had been facing recently. He was supposed to meet Sandeep, his Project Manager at Cut-Edge Private Limited and his team to share his ideas as to how they could cut down the production cost by reducing the wastage they were having due to 
their current steel cutting plan. Aakash was a post graduate in management, and had done good researches in various areas of Operations Management during his MBA. Recently he had joined Cut-Edge Private Limited as the Operations Manager, posted in the regional office of Ahmedabad.

\section{Company Background}

Cut-Edge Private Limited- is one of the biggest steel angle manufacturers in India headquartered in Ahmedabad. The company primarily is into cutting of steel angles for construction of bridges and transmission/power towers. The company's operational activity is to cut steel angles from the various parts available in different lengths. They receive contract-based projects from the government. Currently they are working on a project to build a bridge in Satellite area of Ahmedabad.

\section{Current Practice}

Their current production plan deals with cutting steel angles in various parts for products $\mathrm{A}, \mathrm{B}, \mathrm{C}, \mathrm{D}$ and $\mathrm{E}$ which are to be produced with different lengths and quantities, from 2 types of available materials- ST-90x90x10 of length 12200 millimeter (mm) and ST-90x90x10 of length 11300mm (Exhibit 1).

Exhibit 1 Available Materials

\begin{tabular}{|c|c|c|}
\hline Material Name & $\begin{array}{c}\text { Length } \\
\text { (in mm) }\end{array}$ & Quantity \\
\hline ST-90x90x10 & 12200 & 31 \\
\hline ST-90x90x10 & 11300 & 10 \\
\hline
\end{tabular}

Source: Cut-Edge Private Limited

An additional 100mm of trimming length is cut for every piece of each type of the stock. This trimming length is left for hand holding of the production activity.

Demand of the five parts for the month of April has been shown in Exhibit 2. The different parts A, B, C, D and E can be cut in different combinations based on the availability of material.

Exhibit 2 Requirement of Each Part for the Month of April

\begin{tabular}{|l|c|c|}
\hline Product & Length (in mm) & Quantity \\
\hline Prod A & 940 & 31 \\
\hline Prod B & 6354 & 6 \\
\hline Prod C & 650 & 42 \\
\hline Prod D & 4327 & 35 \\
\hline Prod E & 6730 & 35 \\
\hline
\end{tabular}

Source: Cut-Edge Private Limited

Exhibit 3 shows the details of the parts company produces according to their current practice. 
Exhibit 3 Details of the Parts they Produce According to their Current Practice

\begin{tabular}{|l|c|c|c|c|c|c|c|c|c|}
\hline $\begin{array}{c}\text { Stock } \\
\text { ID }\end{array}$ & $\begin{array}{c}\text { Stock } \\
\text { Length } \\
\text { (in mm) }\end{array}$ & $\begin{array}{c}\text { Stock } \\
\text { Quantity }\end{array}$ & $\begin{array}{c}\text { Off-cut } \\
\text { Length } \\
\text { (in mm) }\end{array}$ & $\begin{array}{c}\text { Prod } \\
\text { E }\end{array}$ & $\begin{array}{c}\text { Prod } \\
\text { B }\end{array}$ & $\begin{array}{c}\text { Prod } \\
\text { D }\end{array}$ & $\begin{array}{c}\text { Prod } \\
\text { A }\end{array}$ & $\begin{array}{c}\text { Prod } \\
\text { C }\end{array}$ & $\begin{array}{c}\text { Cutting Plan } \\
\text { Instruction }\end{array}$ \\
\hline ST 2 & 11300 & 1 & 76 & & 1 & & 3 & 3 & $6354 \times 1 / 940 \times 3 / 650 \times 3$ \\
\hline ST 2 & 11300 & 9 & 143 & 1 & & 1 & & & $6730 \times 1 / 4327 \times 1$ \\
\hline ST 1 & 12200 & 25 & 103 & 1 & & 1 & 1 & & $6730 \times 1 / 4327 \times 1 / 940 \times 1$ \\
\hline ST 1 & 12200 & 1 & 119 & & 1 & 1 & & 2 & $6354 \times 1 / 4327 \times 1 / 650 \times 2$ \\
\hline ST 1 & 12200 & 1 & 170 & 1 & & & & 8 & $6730 \times 1 / 650 \times 8$ \\
\hline ST 1 & 12200 & 3 & 546 & & 1 & & & 8 & $6354 \times 1 / 650 \times 8$ \\
\hline ST 1 & 12200 & 1 & 326 & & 1 & & 3 & 4 & $6354 \times 1 / 940 \times 3 / 650 \times 4$ \\
\hline
\end{tabular}

Source: Cut-Edge Private Limited

Further the current configuration is not able to fulfill the demand of April and has a short-fall of one unit of product $\mathrm{C}$.

\section{Background of the Problem}

On $25^{\text {th }}$ March, the production control department conducted a process check from which they came to know that the off-cut length for their projects is turning out to be huge, thus highly increasing the company's production cost. Off-cut length is the waste left after the steel angles are cut according to required length and trimming length. Due to trimming length of $100 \mathrm{~mm}$ for a stock ST 2, effective available length will be $11,200 \mathrm{~mm}$ for all calculations. After producing the parts whatever length less than $1000 \mathrm{~mm}$ is left, is normally scrap for the company.

On $5^{\text {th }}$ April as and when Sandeep saw process check reports as provided by the production control department, he decided to call for a staff meeting. Sandeep introduced Aakash to the staff as their new operations manager for the current project. He further explained how their current production plan was leading to huge wastage. Thus he gave Aakash the responsibility to strategize various feasible combinations for cutting the five parts such that the company is able to minimize the off-cut length while optimally utilizing the available resources and thus fulfilling the required demand of this month.

\section{Suggested Assignment Questions}

1. For the current project, strategize an effective production plan from various feasible combinations of the five parts for Aakash such that the company is able to minimize the off-cut length and thus optimally utilizing the available resources to meet the order demand for the month of April.

2. What amount of off-cut length was Aakash able to reduce through his suggested plan as compared to the company's current plan? 


\section{Teaching Note}

\section{Teaching Overview}

The case will provide an opportunity to analyse the practical situation through optimization technique. This case will also help to develop constructive pedagogy to discuss the solution of a problem using the LP tool in the courses like Production \& Operations Management, Operations Research and Decision Making.

\begin{tabular}{|c|c|l|}
\hline Sr. No. & Duration & \multicolumn{1}{c|}{ Objective } \\
\hline 1 & 10 & Discussion of case facts and objective \\
\hline 2 & 10 & $\begin{array}{l}\text { Discussion on how LP can be used, while relating the } \\
\text { technique to the case }\end{array}$ \\
\hline 3 & 25 & Discussion of LP formulation of case data \\
\hline 4 & 20 & $\begin{array}{l}\text { Solving the case using Solver- An optimization tool in MS- } \\
\text { Excel }\end{array}$ \\
\hline 5 & 10 & $\begin{array}{l}\text { Final recommendation based on optimal solution and } \\
\text { summary }\end{array}$ \\
\hline
\end{tabular}

\section{Industry Background}

\section{Case Overview}

Steel angles are of two types namely, Hot rolled steel angle and Galvanized steel angle. These steel angles are angled at $90^{\circ}$ that add rigidity and strength to numerous projects. These angles are quite easy to cut and weld. Hot rolled steel angles are used in industry in making constructions equipment's, farm implements, repair projects, fabrication and in manufacturing. Galvanized steel angle is used for braces, supports and framework.

\section{Case Plot}

Sandeep gave information regarding the two available materials Stock ID-1 and Stock ID-2, and also regarding the requirement of different parts as shown in Exhibit 1 and Exhibit 2, respectively. Aakash was also given the details of the current practices of the company to cut the parts from the available stocks which lead to a huge off-cut length (Exhibit 3). Hence Aakash was given the responsibility to design a cutting plan for the on-going project in such a way that the company could reduce their off-cut length, further helping them to reduce the excess cost incurred due to the waste. Further the current configuration is not able to fulfil the demand of April and has a short-fall of one unit of product $\mathrm{C}$.

\section{Decision Variables}

\section{Discussion Questions \& Analysis}

$A_{1}=$ Number of parts produced of product A from Stock ID 1

$\mathrm{B}_{1}=$ Number of parts produced of product B from Stock ID 1

$\mathrm{C}_{1}=$ Number of parts produced of product $\mathrm{C}$ from Stock ID 1

$\mathrm{D}_{1}=$ Number of parts produced of product D from Stock ID 1

$E_{1}=$ Number of parts produced of product $E$ from Stock ID 1 
$\mathrm{A}_{2}=$ Number of parts produced of product A from Stock ID 2

$\mathrm{B}_{2}=$ Number of parts produced of product B from Stock ID 2

$\mathrm{C}_{2}=$ Number of parts produced of product $\mathrm{C}$ from Stock ID 2

$\mathrm{D}_{2}=$ Number of parts produced of product D from Stock ID 2

$E_{2}=$ Number of parts produced of product $E$ from Stock ID 2

$\mathrm{K}=$ Number of ST1 units used while making the different parts

$\mathrm{M}=$ Number of ST2 units used while making the different parts

\section{Objective Functions}

Minimize waste $=$ Off-cut length from ST $1+$ Off-cut length from ST 2

Min $Z=K_{i}(12,200-S T 1)+M_{i}(11,300-S T 2)$

Where, $\mathrm{i}=1,2,3$

\section{Constraints to:}

ST 1: $940 A_{1 i}+6354 B_{1 i}+650 C_{1 i}+4327 D_{1 i}+6730 E_{1 i}+0 A_{2 i}+0 B_{2 i}+0 C_{2 i}+0$ $\mathrm{D}_{2 \mathrm{i}}+0 \mathrm{E}_{2 \mathrm{i}} \leq 12200$

ST 2: $0 A_{1 i}+0 B_{1 i}+0 C_{1 i}+0 D_{1 i}+0 E_{1 i}+940 A_{2 i}+6354 B_{2 i}+650 C_{2 i}+4327 D_{2 i}+$ $6730 \mathrm{E}_{2 \mathrm{i}} \leq 11300$
A: $\mathrm{K}_{1} \mathrm{~A}_{11}+\mathrm{K}_{2} \mathrm{~A}_{12}+\mathrm{K}_{3} \mathrm{~A}_{13}+\mathrm{M}_{1} \mathrm{~A}_{21}+\mathrm{M}_{2} \mathrm{~A}_{22}+\mathrm{M}_{3} \mathrm{~A}_{23} \geq 31$
B: $K_{1} B_{11}+K_{2} B_{12}+K_{3} B_{13}+M_{1} B_{21}+M_{2} B_{22}+M_{3} B_{23} \geq 6$
C: $\mathrm{K}_{1} \mathrm{C}_{11}+\mathrm{K}_{2} \mathrm{C}_{12}+\mathrm{K}_{3} \mathrm{C}_{13}+\mathrm{M}_{1} \mathrm{C}_{21}+\mathrm{M}_{2} \mathrm{C}_{22}+\mathrm{M}_{3} \mathrm{C}_{23} \geq 42$
D: $\mathrm{K}_{1} \mathrm{D}_{11}+\mathrm{K}_{2} \mathrm{D}_{12}+\mathrm{K}_{3} \mathrm{D}_{13}+\mathrm{M}_{1} \mathrm{D}_{21}+\mathrm{M}_{2} \mathrm{D}_{22}+\mathrm{M}_{3} \mathrm{D}_{23} \geq 35$
E: $\mathrm{K}_{1} \mathrm{E}_{11}+\mathrm{K}_{2} \mathrm{E}_{12}+\mathrm{K}_{3} \mathrm{E}_{13}+\mathrm{M}_{1} \mathrm{E}_{21}+\mathrm{M}_{2} \mathrm{E}_{22}+\mathrm{M}_{3} \mathrm{E}_{23} \geq 35$
$A_{1 i}, B_{1 i}, C_{1 i}, D_{1 i}, E_{1 i}, A_{2 i}, B_{2 i}, C_{2 i}, D_{2 i}, E_{2 i}, K_{1}, K_{2}, K_{3}, M_{1}, M_{2}, M_{3} \geq 0$

The requirement of each part for the month of April is shown in Exhibit 2. For the above LP formulation, Aakash suggested an optimal solution obtained using Solverthe optimizing tool of MS Excel. The new configuration of each part as suggested by Aakash is shown in Exhibit 5.

\section{Question: 1}

Strategize an effective production plan for Aakash for the current project, including the various feasible combinations of the five parts such that the company can minimize the off-cut length using those combinations by utilizing the available resources optimally?

Solution of LP formulation using Solver in MS-Excel as suggested by Aakash is shown in Exhibit 5. This new configuration provides the optimal solution. This new configuration suggests the following units of each product.

Exhibit 4 New configured solution

\begin{tabular}{|c|c|}
\hline Product Name & Optimum Quantity \\
\hline A & 31 \\
\hline B & 6 \\
\hline C & 42 \\
\hline D & 35 \\
\hline E & 35 \\
\hline
\end{tabular}


The above-mentioned plan fulfils the minimum requirement of the company by optimally utilizing all the resources and also reducing the waste generated during the cutting process.

\section{Question: 2}

How much amount of off-cut length was Aakash able to reduce through his suggested plan as compared to the company's current plan?

According to Exhibit3, Original off-cut length $=6191 \mathrm{~mm}$

According to Exhibit-5, New off-cut length $=5541 \mathrm{~mm}$

Amount of off-cut length reduced by using the new cutting plan $=6191-5541=650 \mathrm{~mm}$

Exhibit 5: Details of the parts company should produce according to Aakash

\begin{tabular}{|c|c|c|c|c|c|c|c|c|c|}
\hline $\begin{array}{l}\text { Stock } \\
\text { ID }\end{array}$ & $\begin{array}{c}\text { Stock } \\
\text { Length }\end{array}$ & $\begin{array}{c}\text { Stock } \\
\text { Quantity }\end{array}$ & $\begin{array}{c}\text { Off- } \\
\text { cut } \\
\text { Length }\end{array}$ & $\begin{array}{c}\text { Prod } \\
\text { A } \\
940\end{array}$ & $\begin{array}{c}\text { Prod } \\
\text { B } \\
6354\end{array}$ & $\begin{array}{c}\text { Prod } \\
\text { C } \\
650\end{array}$ & $\begin{array}{c}\text { Prod } \\
\text { D } \\
4327 \\
\end{array}$ & $\begin{array}{c}\text { Prod } \\
\text { E } \\
6730\end{array}$ & $\begin{array}{l}\text { Cutting Plan } \\
\text { Instruction }\end{array}$ \\
\hline ST 1 & 12200 & 25 & 203 & 1 & 0 & 0 & 1 & 1 & $940 \times 1 / 4327 \times 1 / 6730 \times 1$ \\
\hline ST 1 & 12200 & 6 & 354 & 1 & 1 & 7 & 0 & 0 & $940 \times 1 / 6354 \times 1 / 650 \times 7$ \\
\hline ST 2 & 11300 & 9 & 243 & 0 & 0 & 0 & 1 & 1 & $4327 \times 1 / 6730 \times 1$ \\
\hline ST 2 & 11300 & 1 & 243 & 0 & 0 & 0 & 1 & 1 & $4327 \times 1 / 6730 x 1$ \\
\hline & & $\begin{array}{c}\text { Total } \\
\text { Off-cut } \\
\text { Length }\end{array}$ & 5541 & & & & & & \\
\hline
\end{tabular}

